115

\title{
THE ORAL HISTORY OF FORGOTTEN WARS: THE MEMOIRS OF VETERANS OF THE WAR IN ANGOLA
}

\section{Compiled and edited by Gennady Shubin \\ Translated by Peter Sidorov}

Moscow: Memories Publishers, 2007

91 pages

Maps and photos

ISBN: 978-5-903116-40-9

Price unknown

With the commemoration of the battles around Cuito Canavale coming up, various authors are striding Angolan battlefields again. In South Africa a variety of publications is seeing the light. Unfortunately many of these are by former senior officers highlighting their own interpretation of the war, as did many previous publications in South Africa. Many publications here are espousing one side of the war. The role of Special Forces is but one example. This trend was set in the 1980s and seems to continue in South Africa. The role of Special Forces - as if others were not involved - deserves a lot of attention. More so the role of other actors such as the Angolan armed forces (FAPLA), the Cubans and the Soviets is mostly ignored except for some stereotyping underpinned by an ideology from times gone by indeed a sad state of affairs.

Over the past years a host of highly informative publications appeared by other actors. The invasion of Angola by apartheid South Africa's armed forces where more than 140 small and large scale operations frequently dovetailed marked the constant violation of the sovereignty and the airspace of Angola. Related to this various publications by the Angolans, Russians and Cubans appeared. Sadly South African publishers ignored these and they were/are not translated into English or Afrikaans thus denying South Africans, especially those that experienced the war intimately, from seeing the war through the eyes of FAPLA, the Cubans and Russian advisors and interpreters. The Cubans have published various works covering the era from Savanna (1976/1977) to Cuito Canavale (1987/1988) as well as the memoirs of Cuban pilots involved during this era. Of these South Africans know very little or nothing. 
The particular contribution reviewed here consists of a compilation of interviews with two Soviet officers and relate amongst others to Cuito Canavale. It is another noticeable contribution. The book appeared in English, thus accessible to the average South African reader.

Shubin interviewed two participants of the Angolan war, namely Colonel Vyacheslav Alexandrovich Mityaev and senior lieutenant Anatoly Alekseevsky of the Soviet reserve forces. Mityaev shares with the reader not only his experiences about the battles around Cuito, but also about his training in the Soviet armed forces and deployment in Afghanistan. For those interested in weaponry both the interviewees share much about the hardware deployed by the forces involved. I found it extremely interesting. Intermingled with these we find the personal experiences of these veterans, both negative and positive. Mityaev describes how the Soviet Union was drawn into the Afghanistan conflict to support the then secular government. He explains why the personal arms of soldiers in Afghanistan were once again returned to $7.62 \times 39 \mathrm{~mm}$ rather than the $5.45 \times 39 \mathrm{~mm}$ used previously. The latter caliber increasingly proved to be ineffective under the battle conditions experienced in Afghanistan.

About the Angolan war Mityaev points out basic mistakes in South African knowledge of the war. Amongst these are wrong names attributed to senior Soviet staff deployed in Angola. The book by Jannie Geldenhuys (uncorrected in the second edition) is an example. Geldenhuys and some South African historiographers still suggest that a General Shaganovich was a chemical expert involved in the Angolan theatre. In fact a person with the name of Shaganovich never existed, nor was involved with the use of chemical weapons. In fact the Angolans, Cubans or Soviets did not use chemical weapons in the war.

The interviewee vividly describes contact scenes and experiences of FAPLA soldiers and attacks by Unita, ally of the apartheid forces, as well as the SAAF activities around Cuito before the South Africans lost air superiority. The South Africans reliance on artillery i.e. the G-5, G-6 and the $127 \mathrm{~mm}$ multiple rocket launchers (Valkiri) are described and criticized. Artillery does not win battles, despite what Napoleon suggested. It only contributes to eventual victory. The real job is done by the infantry, armour and the air forces. For the interviewee this was an important tactical mistake by the South Africans at Cuito.

Alekseevsky provides the perspective from a more junior officer'side. He describes Unita as "simply bandits" that terrorized the local community in order to 


\section{7}

win the hearts and the minds of Angolans. This made Unita deeply unpopular. The end result years later were that Unita dwindled in support and soldiers deserted en masse. Eventually Jonas Savimbi was killed by Angolan security forces as an unpopular and isolated man. The interviewee discloses that Unita forces at Cuito in many cases could not retrieve the wounded and their dead, that in various cases contacts took place between 400 and 500 metres, that no Soviet snipers were involved (indeed no SVD sniper rifles were available), that the artillery available at Cuito by FAPLA could not match those used by the apartheid forces. He reveals that Strela missiles succeeded in dislodging South African air attacks. He reports that he saw one South African aircraft shot down and another damaged during attacks. On a more personal level he shares with us that in the absence of supplies Soviet soldiers creatively developed a "home distilling device". Soldiers do not only march on their stomachs - this we know from various earlier wars, be it at sea or on land!

The appendix of photos is most welcome and illustrates the experiences of these men well. This compilation of interviews brought together by Gennady Shubin (translated by Peter Sidorov) is a most welcome contribution to a growing arsenal of publications on the role of other stakeholders in a war that left Angola with an unprecedented refugee crises and destruction of infrastructure, not to speak of agricultural potential and the legacy of millions of landmines. It is a pity that this publication is not widely available and it is unlikely that navel-staring South African publishers will ever undertake to publish it here or translate it into any of our native South African languages.

Ian Liebenberg, Centre for Military Studies and Department of Political Science, Military Academy of South Africa, Saldanha 